\title{
Correlation between Serum Vitamin D Deficiency and Early Spontaneous Pregnancy Loss
}

\author{
Dr. Mst. Sharmin Ferdous ${ }^{1 *}$, Prof. Farhat Hussain ${ }^{2}$, Dr. Samira Hayee ${ }^{3}$, Prof. Nahreen Akhtar ${ }^{4}$, Dr. Suraiya Khanam ${ }^{5}$, Dr. \\ Chowdhury Shamima Sultana ${ }^{6}$, Dr. Kabita Saha ${ }^{7}$ \\ ${ }^{1}$ Medical Officer, Department of Feto Maternal Medicine, Bangabandhu Sheikh Mujib Medical University, Dhaka, Bangladesh \\ ${ }^{2}$ Professor, Department Obstetrics \& Gynecology, Sir Salimullah Medical College and Mitford Hospital, Dhaka, Bangladesh \\ ${ }^{3}$ MD Resident, Department of Neurology, National Institute Neurosciences \& Hospital (NINS), Dhaka, Bangladesh \\ ${ }^{4}$ Professor \& Head of Department, Department of Feto Maternal Medicine, Bangabandhu Sheikh Mujib Medical University, Dhaka, \\ Bangladesh \\ ${ }^{5}$ Medical Officer, Department of Gynecological Oncology, Bangabandhu Sheikh Mujib Medical University, Dhaka, Bangladesh \\ ${ }^{6}$ Department of Gynecological Oncology, National Institute of Cancer Research \& Hospital (NICRH), Dhaka, Bangladesh \\ ${ }^{7}$ Medical Officer, Department of Obstetrics \& Gynecology, Dhaka Medical College \& Hospital, Dhaka, Bangladesh
}

DOI: $10.36348 /$ sijog.2021.v04i04.009

| Received: 05.03.2021 | Accepted: 02.04.2021 | Published: 19.04.2021

*Corresponding author: Dr. Mst. Sharmin Ferdous

\section{Abstract}

Background: Miscarriage is the most common negative outcome in pregnancy worldwide. Its identification of modifiable risk factors is playing an important role in public health. Low vitamin D concentrations in pregnancy are widespread worldwide and the effects of vitamin D deficiency in pregnancy have been associated with some adverse pregnancy outcomes. We have very limited research-oriented information regarding the correlation between serum vitamin D deficiency and early spontaneous pregnancy loss. Aim of the study: The aim of this study was to evaluate the association of maternal serum vitamin D deficiency with early spontaneous pregnancy loss. Methods \& Materials: This case-control study was carried out in the Department of Obstetrics and Gynaecology, Sir Salimullah Medical College and Mitford Hospital, Dhaka, Bangladesh during the period from September 2018 to August 2019. A total of 100 patients, 50 pregnant women having early spontaneous pregnancy loss (documented by ultrasonography as missed or incomplete abortion) was considered as the case (Group I). Age, gestational age and BMI matched another 50 women in their early live pregnancy (documented by ultrasonography) was served as control (Group II) in this study. The biochemical parameter measured in this study included fasting serum 25 -hydroxy vitamin D level. Serum $25(\mathrm{OH}) \mathrm{D}$ level<20 ng/ml was classified as vitamin D deficiency and $<10 \mathrm{ng} / \mathrm{ml}$ was classified as vitamin D severe deficiency. Statistical analyses of the results were obtained by using window-based computer software devised with SPSS version 22.0. Results: In analyzing vitamin D level $(\mathrm{ng} / \mathrm{ml})$ of the participants of this study it was found that more than half $(52.0 \%)$ patients had severe deficiency $(<10 \mathrm{ng} / \mathrm{ml})$ in group I and $14(28.0 \%)$ patients in group II. 24(48.0\%) patients had deficiency (10-20 $\mathrm{ng} / \mathrm{ml})$ in group I and 35(70.0\%) in group II. Only 1(2.0\%) patient had insufficiency (21-29 ng/ml) in group II. None of the patients had sufficient serum vitamin D levels. In comparing the serum vitamin D level (ng/ml) between group I and group II it was observed that the mean vitamin D level was $9.98 \pm 2.56 \mathrm{ng} / \mathrm{ml}$ in group I and $11.51 \pm 2.96 \mathrm{ng} / \mathrm{ml}$ in group II. The difference was statistically significant $(\mathrm{p}<0.05)$ between the two groups. Conclusion: Serum Vitamin D was significantly low in women with early spontaneous pregnancy loss as compared to pregnant women with early live pregnancy. Serum Vitamin D was deficient predominantly in both cases and control. Maternal serum vitamin D deficiency was significantly associated with early spontaneous pregnancy loss.

Keywords: Serum vitamin D, gestational age, miscarriage, early spontaneous pregnancy loss.

Copyright $\odot 2021$ The Author(s): This is an open-access article distributed under the terms of the Creative Commons Attribution 4.0 International License (CC BY-NC 4.0) which permits unrestricted use, distribution, and reproduction in any medium for non-commercial use provided the original author and source are credited.

\section{INTRODUCTION}

Pregnancy loss (PL) is an adverse outcome of pregnancy in which conception does not result in a lifeborn child [1]. Spontaneous pregnancy loss is seen in approximately $10-15 \%$ of clinically observed pregnancies. Early pregnancy loss (spontaneous abortion) is assigned when the loss occurs before the completion of 12 weeks' gestation [2]. A thorough study of the pathophysiology behind this adverse 
Sharmin Ferdous et al; Sch Int J Obstet Gynec, Apr. 2021; 4(4): 131-135

pregnancy outcome is of great importance. A lot of mechanisms have been proposed in this regard, including chromosomal anomalies, hormonal derangements, infections, uterine fibroid (submucous), uterine synechiae, inherited thrombophilia, and autoimmune disorders. In approximately $50 \%$ of cases with early pregnancy loss, the causes remain enigmatic in which the loss is termed unexplained pregnancy loss [3]. Vitamin D3(1, 25 dihydroxy vitamin D3) is a hormone that is lipid-soluble and well known to function in promoting bone mineralization and maintaining calcium homeostasis [4]. Vitamin D3 also plays a major role in controlling cell proliferation and maturation and in modulating the immune response in both innate and adaptive forms [5]. Vitamin D metabolic pathway involves multiple enzymatic reactions. Vitamin D is metabolized in the liver to the form $25(\mathrm{OH}) \mathrm{D}$, which is used to determine a patient's vitamin $\mathrm{D}$ status; $25(\mathrm{OH}) \mathrm{D}$ is metabolized in the kidneys by 25-hydroxyvitamin D-1 alpha-hydroxylase (CYP27B1) to its active form, 1,25(OH)2D [6]. The increased synthesis of $1,25(\mathrm{OH}) 2 \mathrm{D}$ is linked to higher CYP27B1 activity in the maternal kidney, placental trophoblasts, and Deciduas [7]. To date, little is known regarding the determinants of the levels of CYP27B1 in serum, nor a possible association between the level of the enzymes in early pregnancy loss has been explored. A lot of epidemiological published literature refers to the global occurrence of Vitamin D deficiency and insufficiency [8]. In a study they recorded the Vitamin D deficiency incidence (a serum level of $<20 \mathrm{ng} / \mathrm{mL}$ ) in women during reproductive age to be $31 \%$. Reports from the "National Health and Nutrition Examination Surveys" described that the problem is variable between racial and ethnic categories, "with non-Hispanic blacks possessing a higher rate of Vitamin D deficiency and" insufficiency when compared to white ethnic groups [9]. These results were supported "by Forrest and Stuhldreher, who registered" that blacks had the highest incidence of Vitamin D insufficiency $(82.1 \%)$ and then followed by Hispanics (69.2\%) [10]. In spite of its global prevalence, wide geographical screening for vitamin insufficiency has not been adopted because of the expensive serum assays. For that reason, screening has been carried out only for groups at great risk for vitamin D deficiency [11]. Recently, a great deal of attention has been focused on vitamin status during pregnancy. Evidence about the role of vitamin D in human reproduction has been proved by a number of researchers [12]. Globally, vitamin D deficiency is a frequent problem among women at the age of childbearing [13]. The objective of this study was to elucidate the association of maternal serum vitamin D deficiency with early spontaneous pregnancy loss.

\section{OBJECTIVES}

\section{General Objective}

- To evaluate the association of maternal serum Vitamin D deficiency with early spontaneous pregnancy loss.

\section{Specific Objective}

- To estimate the maternal serum Vitamin D level in patients with early spontaneous pregnancy loss.

- To find out the association of maternal serum vitamin D deficiency in case and control.

\section{METHODOLOGY \& MATERIALS}

This case-control study was carried out in the Department of Obstetrics and Gynaecology, Sir Salimullah Medical College Mitford Hospital, Dhaka, Bangladesh from September 2018 to August 2019. A total of 100 patients were included in this study. Among them, 50 pregnant women having early spontaneous pregnancy loss (documented by ultrasonography as missed or incomplete abortion) was considered as a case (Group I). Age, gestational age, and BMI matched another 50 women in their early live pregnancy (documented by ultrasonography) was served as control (Group II). A purposive sampling method was used in this study. According to the inclusion criteria of this study women having regular menstrual cycles, 21- 35 years of age, BMI within the range of $18.5-29.9 \mathrm{~kg} / \mathrm{m} 2$ were included. Besides these, cases were pregnant women with early spontaneous pregnancy loss. Gestational age and BMI matched pregnant women with early live pregnancy comprised the control subjects. On the other hand, according to the exclusion criteria of this study pregnant women using vitamin D or hormone at least 3 months prior to enrollment or with multiple pregnancies, an autoimmune disorder, chromosomal abnormality, thyroid dysfunction, diabetes mellitus, renal dysfunction, and malignancy were excluded. Age of the patient, occupation, education, locality or area of residence, socio-economic condition, and personal behavior were considered as demographic variables of this study. Gestational age and number of pregnancy loss were the obstetric variables. Anthropometric variables were height(M), weight $(\mathrm{Kg})$ and $\mathrm{BMI}(\mathrm{Kg} / \mathrm{m} 2)$. Serum vitamin D level 25(OH)D (ng $/ \mathrm{ml}$ ) was considered as a Biochemical variable. The gestational age was calculated from the last menstruation period(LMP) and ultrasonography. All the subjects attending and Out-Patient Department of Obstetrics and Gynaecology, Sir Salimullah Medical College Mitford Hospital, Dhaka, Bangladesh during the study period and who fulfilled the inclusion criteria were enrolled in the study. A physical examination of all the participants was done. The demographic and obstetrics information was collected in a pre-structured datasheet. The body weight of the participants was measured barefooted. The average weight $(0.5 \mathrm{~kg})$ of the clothes was later subtracted from the measured weight. The measurement of weight was done after the bladder has been emptied and before a meal. The heights of the subjects were measured barefooted in the standing position with meter scales. Body mass index was determined by measuring weight $(\mathrm{kg})$ divided by height square(meter). The blood sample was collected for measurement of $25(\mathrm{OH}) \mathrm{D}$ levels. Vitamin $\mathrm{D}$, in the 
Sharmin Ferdous et al; Sch Int J Obstet Gynec, Apr. 2021; 4(4): 131-135

form of $25(\mathrm{OH}) \mathrm{D}$ estimation was carried out by a chemiluminescent microparticle immunoassay using the ARCHITECT in the laboratory of the biochemistry department of BSMMU. Vitamin D levels were defined as 'Severe deficiency: $<10 \mathrm{ng} / \mathrm{ml}$ ', 'Deficiency: 10-20 $\mathrm{ng} / \mathrm{ml}$ ', 'Insufficiency: 21-29 $\mathrm{ng} / \mathrm{ml}$ ', and 'Sufficiency: $\geq 30 \mathrm{ng} / \mathrm{ml}$ '14. Statistical analyses of the results were obtained by using window-based computer software devised with SPSS version 22.0.

\section{RESULT}

In this study, it was observed that $40(80.0 \%)$ patients belonged to age 20-25 years in group I and $34(68.0 \%)$ in group II. The mean age was $22.88 \pm 1.88$ years in group I and $23.96 \pm 3.56$ years in group II. The majority of the patients had normal BMI in both groups. The mean BMI was $22.26 \pm 1.52 \mathrm{~kg} / \mathrm{m} 2$ in group I and $22.35 \pm 1.4 \mathrm{~kg} / \mathrm{m} 2$ in group II. None of the demographic parameters were statistically significant. It was also observed that the majority $(86.0 \%)$ of patients in group I and $41(82.0 \%)$ patients in group II had sunlight exposure for $<1 / 2$ hour. The majority $(90.0 \%)$ of the patients wore a veil in group I and $44(88.0 \%)$ in group II. The difference was statistically not significant ( $p>0.05$ ) between the two groups. In analyzing vitamin D level $(\mathrm{ng} / \mathrm{ml})$ of the participants of this study it was found that more than half $(52.0 \%)$ patients had severe deficiency $(<10 \mathrm{ng} / \mathrm{ml})$ in group I and $14(28.0 \%)$ patients in group II. $24(48.0 \%)$ patients had deficiency $(10-20 \mathrm{ng} / \mathrm{ml})$ in group I and $35(70.0 \%)$ in group II. Only $1(2.0 \%)$ patient had insufficiency $(21-29 \mathrm{ng} / \mathrm{ml})$ in group II. None of the patients had sufficient serum vitamin D levels. In comparing the serum vitamin D level (ng/ml) between group I and group II it was observed that the mean vitamin D level was $9.98 \pm 2.56$ $\mathrm{ng} / \mathrm{ml}$ in group I and $11.51 \pm 2.96 \mathrm{ng} / \mathrm{ml}$ in group II. The difference was statistically significant $(\mathrm{p}<0.05)$ between the two groups.

Table-1: Age distribution of participants ( $N=100)$

\begin{tabular}{|l|l|l|l|l|}
\hline \multirow{2}{*}{ Age (in years) } & \multicolumn{2}{l|}{ Group I } & \multicolumn{2}{l|}{ Group II } \\
\cline { 2 - 5 } & \multicolumn{2}{|l|}{$(\mathbf{n = 5 0})$} & \multicolumn{2}{l|}{$(\mathbf{n}=\mathbf{5 0})$} \\
\cline { 2 - 5 } & $\mathbf{n}$ & $\mathbf{\%}$ & $\mathbf{n}$ & $\mathbf{\%}$ \\
\hline $21-25$ & 40 & 80.0 & 34 & 68.0 \\
\hline $26-30$ & 9 & 18.0 & 13 & 26.0 \\
\hline $31-35$ & 1 & 2.0 & 3 & 6.0 \\
\hline
\end{tabular}

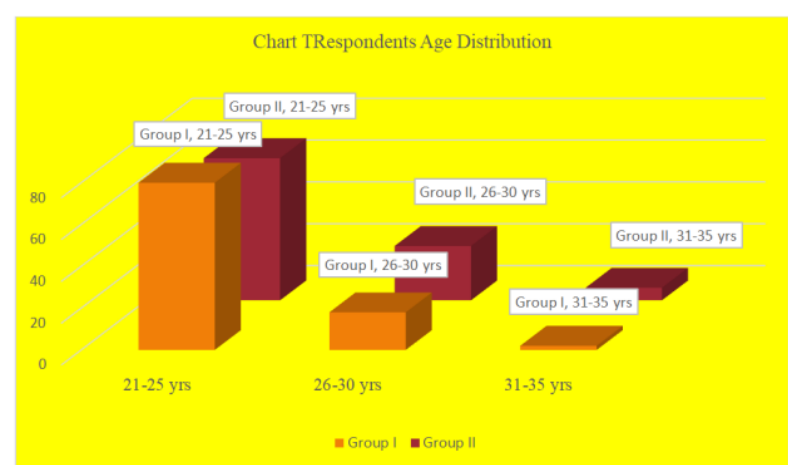

Fig-1: Participants Age Distribution

\begin{tabular}{|l|l|l|l|l|}
\hline Table-2: BMI distribution of participants (N=100) \\
\hline \multirow{3}{*}{ BMI kg/m2 } & \multicolumn{2}{|l|}{ Group I } & \multicolumn{2}{l|}{ Group II } \\
\cline { 2 - 5 } & $\mathbf{( n = 5 0 )}$ & \multicolumn{2}{|l|}{$(\mathbf{n = 5 0 )}$} \\
\cline { 2 - 5 } & $\mathbf{n}$ & $\mathbf{\%}$ & $\mathbf{n}$ & $\mathbf{\%}$ \\
\hline Normal (18.5-24.9) & 44 & 88.0 & 46 & 92.0 \\
\hline Overweight (25-29.9) & 6 & 12.0 & 4 & 8.0 \\
\hline Base & 50 & 100.0 & 50 & 100.0 \\
\hline
\end{tabular}

Table-3: Distribution of the study population according to vitamin $D$ level in $\mathrm{ng} / \mathrm{ml}(\mathrm{N}=100)$

\begin{tabular}{|l|l|l|l|l|}
\hline \multirow{3}{*}{ Vitamin D level ng/ml } & \multicolumn{2}{|l|}{ Group I } & \multicolumn{2}{l|}{ Group II } \\
\cline { 2 - 5 } & \multicolumn{2}{|l|}{$(\mathbf{n = 5 0})$} & \multicolumn{2}{l|}{$(\mathbf{n = 5 0})$} \\
\cline { 2 - 5 } & $\mathbf{n}$ & $\mathbf{\%}$ & $\mathbf{n}$ & \% \\
\hline Severe deficiency $<10$ & 26 & 52.0 & 14 & 28.0 \\
\hline Deficiency 10-20 & 24 & 48.0 & 35 & 70.0 \\
\hline Insufficiency 21-29 & 0 & 0.0 & 1 & 2.0 \\
\hline Sufficiency $(\geq 30)$ & 0 & 0.0 & 0 & 0.0 \\
\hline
\end{tabular}

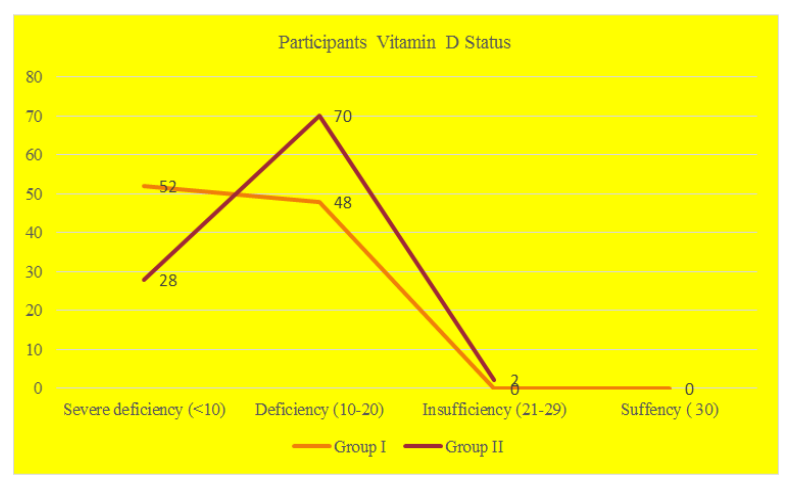

Fig-2: Participants Vitamin D Status

Table-4: Comparison of Vit. D level between the groups $(\mathrm{N}=100)$

\begin{tabular}{|l|l|l|}
\hline \multirow{2}{*}{ Vit. D level ng/ml } & Group I & Group II \\
\cline { 2 - 3 } & Case & Control \\
\cline { 2 - 3 } & $\mathbf{( n = 5 0 )}$ & $\mathbf{( n = 5 0 )}$ \\
\hline Mean \pm SD & $9.98 \pm 2.56$ & $11.51 \pm 2.96$ \\
\hline Range (min-max) & $6.7-14.5$ & $8.8-21.7$ \\
\hline P value & $\mathrm{P}<0.01$ \\
\hline
\end{tabular}

\section{DISCUSSION}

The aim of this study was to evaluate the association of maternal serum Vitamin D deficiency with early spontaneous pregnancy loss. In this present study, it was observed that the majority of the patients had normal BMI in both groups. The mean BMI was $22.26 \pm 1.52 \mathrm{~kg} / \mathrm{m} 2$ in group I and $22.35 \pm 1.4 \mathrm{~kg} / \mathrm{m} 2$ in group II. The difference was statistically not significant $(p>0.05)$ between the two groups. In a study by Ghaedi et al., [15] It was found that $66.7 \%$ of those with SPL and $58.3 \%$ of the women with RPL had normal BMI. In another study, Andersen et al., [16] observed that the maternal BMI was $23.26 \mathrm{~kg} / \mathrm{m} 221.01-27.18 \mathrm{~kg} / \mathrm{m} 2$ in group I and $23.38 \mathrm{~kg} / \mathrm{m} 2$ varied from 21.26-26 [18] $\mathrm{kg} / \mathrm{m} 2$ in group II, which is similar to the present study. In this current study, it was observed that $52.0 \%$ patients had severe deficiency $(<10 \mathrm{ng} / \mathrm{ml})$ and $48.0 \%$ in deficiency $(10-20 \mathrm{ng} / \mathrm{ml})$. The mean vitamin D level 
was $9.98 \pm 2.56 \mathrm{ng} / \mathrm{ml}$ varied from $6.7-14.5 \mathrm{ng} / \mathrm{ml}$. Sharif et al., [17] found the mean vitamin D level was $11.5 \pm 3.1 \mathrm{ng} / \mathrm{ml}$ in women with a history of pregnancy loss, which is comparable with the present study. Kuhr et al., [18] observed $25.6 \%$ of patients had a deficiency and $74.4 \%$ had insufficiency. Kota et al., [19] observed that $41.4 \%$ had women with pregnancy loss were vitamin $\mathrm{D}$ deficient. In this current study, it was observed that the mean vitamin D level was $9.98 \pm 2.56$ $\mathrm{ng} / \mathrm{ml}$ in group I and $11.01 \pm 2.96 \mathrm{ng} / \mathrm{ml}$ in group II. The difference was statistically significant $(p<0.05)$ between the two groups. Similarly, Li et al., [20] also found that serum vitamin D level was significantly decreased in pregnancy loss $(42.49 \pm 11.17 \mu \mathrm{g} / \mathrm{L})$ when compared to the control group $(50.57 \pm 3.18 \mathrm{mg} / \mathrm{L})$ suggesting that an altered localized maternal vitamin $D$ state may influence pregnancy outcome. In this current study, it was observed that $52.0 \%$ of patients had severe deficiency $<10 \mathrm{ng} / \mathrm{ml}$ in group I and $28.0 \%$ of patients in group II. $48.0 \%$ of patients had deficiency $10-20$ $\mathrm{ng} / \mathrm{ml}$ in group I and $70.0 \%$ in group II. Only $2.0 \%$ of patients had insufficiency $21-29 \mathrm{ng} / \mathrm{ml}$ in group II. The difference was statistically significant $(\mathrm{p}<0.05)$ between the two groups. Adequate vitamin D concentrations were essential during pregnancy. Vitamin D deficiency in the mother could be vertically transmitted to the fetus. Hou et al., [1] also found that the early pregnancy loss women had significantly lower vitamin D levels than normal early pregnant women and had a low vitamin D rate of $43.3 \%$; however, $96.7 \%$ of normal early pregnant women revealed vitamin $\mathrm{D}$ sufficient. The risk of pregnancy loss in pregnant women with a low concentration of vitamin D is 1.71 with $95 \% \mathrm{CI}$ : 1.2-2.4. It means that vitamin $\mathrm{D}$ deficiency was associated with PL in the first-trimester pregnancy. Andersen et al., [16] found the association between Vitamin D insufficiency and first-trimester miscarriages. Kuhr et al., [18] observed $25.6 \%$ of patients had a deficiency and $74.4 \%$ had insufficiency in women with recurrent pregnancy loss. In another study by Kota et al., [19] observed that $41.4 \%$ had women with pregnancy loss were vitamin D deficient. Worldwide, Vitamin D (VD) deficiency during pregnancy is prevalent and recent studies reported an association between low VD levels and Recurrent pregnancy loss (RPL) [21].

\section{LIMITATIONS OF THE STUDY}

This was a single-centered short lengthen study with a small sample size. So, the findings of this study may not reflect the exact scenario of the whole country. Samples were taken by the purposive method in which questions of personal biases might arise. Confounding variables for vitamin D deficiency could not be excluded.

\section{CONCLUSION AND RECOMMENDATIONS}

Serum vitamin D deficiency is evident in almost all the study subjects but it is significantly lower in pregnant women with early spontaneous pregnancy loss than in control. For getting more reliable information we would like to recommend conducting more studies in several places with large samples. We can consider serum vitamin $\mathrm{D}$ as a screening test in the pre-conceptional period and intervention programs for raising vitamin D levels in those women can be carried out in order to prevent vitamin D deficiency linked to pregnancy loss.

\section{REFERENCES}

1. Hou, W., Yan, X. T., Bai, C. M., Zhang, X. W., Hui, L. Y., \& Yu, X. W. (2016). Decreased serum vitamin D levels in early spontaneous pregnancy loss. European journal of clinical nutrition, 70(9), 1004-1008.

2. Yinping, H. (2008). Spontaneous abortion. In: Yue J, editor. Obstetrics and Gynaecology. 7th ed. Beijing: People's Health Publishing House, pp.83-86.

3. Practice Committee of the American Society for Reproductive Medicine, 2012. Evaluation and treatment of recurrent pregnancy loss: a committee opinion. Fertility and Sterility, 98(5), pp.1103-1111.

4. Holick, M. F. (2007). Vitamin D deficiency. New England Journal of Medicine, 357(3), 266281.

5. Lagishetty, V., Liu, N. Q., \& Hewison, M. (2011). Vitamin D metabolism and innate immunity. Molecular and cellular endocrinology, 347(1-2), 97-105.

6. Christakos, S., Dhawan, P., Benn, B., Porta, A., Hediger, M., Oh, G. T., Jeung, E. B., Zhong, Y., Ajibade, D., Dhawan, K., \& Joshi, S. (2007). Vitamin D: molecular mechanism of action. Annals of the New York Academy of Sciences, 1116(1), pp.340-348.

7. Diaz, L., Sánchez, I., Avila, E., Halhali, A., Vilchis, F., \& Larrea, F. (2000). Identification of a 25-hydroxyvitamin D3 1á-hydroxylase gene transcription product in cultures of human syncytiotrophoblast cells. The Journal of Clinical Endocrinology \& Metabolism, 85(7), 2543-2549.

8. Mitchell, D., Henao, M., Finkelstein, J., \& Burnett-Bowie, S. A. (2012). Prevalence and predictors of vitamin D deficiency in healthy adults. Endocrine Practice, 18(6), 914-923.

9. Looker, A. C., Johnson, C. L., Lacher, D. A., Pfeiffer, C. M., Schleicher, R. L., \& Sempos, C. T. (2011). Vitamin D status: United states, 2001-2006. NCHS data brief, 59(59), 1-8.

10. Forrest, K. Y., \& Stuhldreher, W. L. (2011). Prevalence and correlates of vitamin D deficiency in US adults. Nutrition research, 31(1), 48-54.

11. Kennel, K. A., Drake, M. T., \& Hurley, D. L. (2010, August). Vitamin D deficiency in adults: when to test and how to treat. In Mayo Clinic Proceedings, 85(8), 752-758. 
12. Lerchbaum, E., \& Rabe, T. (2014). Vitamin D and female fertility. Current Opinion in Obstetrics and Gynaecology, 26(3), 145-150.

13. Woo, J., Lam, C. W., Leung, J., Lau, W. Y., Lau, E., Ling, X., Xing, X., Zhao, X. H., Skeaff, C. M., Bacon, C. J., \& Rockell, J. E. (2008). Very high rates of vitamin $\mathrm{D}$ insufficiency in women of child-bearing age living in Beijing and Hong Kong. British Journal of Nutrition, 99(6), pp.1330-1334.

14. Flood-Nichols, S. K., Tinnemore, D., Huang, R. R., Napolitano, P. G., \& Ippolito, D. L. (2015). Vitamin D deficiency in early pregnancy. PLoS One, 10(4), e0123763.

15. Ghaedi, N., Forouhari, S., Zolghadri, J., Sayadi, M., Nematollahi, A., \& Khademi, K. (2016). Vitamin D deficiency and recurrent pregnancy loss in Iranian women. Glob. Adv. Res. J. Medic. Med. Sc., 5(6), 194-198.

16. Andersen, L. B., Jørgensen, J. S., Jensen, T. K., Dalgård, C., Barington, T., Nielsen, J., BeckNielsen, S. S., Husby, S., Abrahamsen, B., Lamont, R. F., \& Christesen, H. T. (2015). Vitamin D insufficiency is associated with increased risk of first-trimester miscarriage in the Odense Child Cohort. The American Journal of Clinical Nutrition, 102(3), 633-638.

17. Shareif, P. D. M., Mahmood D. S. K., \& AlAbassy, D. N. H. (2018). The Association of
Serum Vitamin D and Calcium Levels with Early Recurrent Spontaneous Pregnancy Loss. Journal of medical science and clinical research, 6(11), 272-277.

18. Kuhr, D. L., Sjaarda, L. A., Alkhalaf, Z., Omosigho, U. R., Connell, M. T., Silver, R. M., ... \& Mumford, S. L. (2018). Vitamin D is associated with bioavailability of androgens in eumenorrheic women with prior pregnancy loss. American journal of obstetrics and gynecology, 218(6), 608 e1.

19. Kota, A. K., Kwon, G., Choi, W., Mabry, J. M., \& Tuteja, A. (2012). Hygro-responsive membranes for effective oil-water separation. Nature communications, 3(1), 1-8.

20. Li, N., Wu, H. M., Hang, F., Zhang, Y. S., \& Li, M. J. (2017). Women with recurrent spontaneous abortion have decreased $25(\mathrm{OH})$ vitamin $\mathrm{D}$ and VDR at the fetal-maternal interface. Brazilian Journal of Medical and Biological Research, 50(11).

21. Ota, K., Dambaeva, S., Han, A. R., Beaman, K., Gilman-Sachs, A., \& Kwak-Kim, J. (2014). Vitamin D deficiency may be a risk factor for recurrent pregnancy losses by increasing cellular immunity and autoimmunity. Human reproduction, 29(2), 208-219. 